\title{
Integracja europejska w mikroperspektywie. Graniczne miasta bliźniacze w Europie Zachodniej i Środkowo-Wschodniej
}

\section{Wprowadzenie}

$\mathrm{O}$ statnie dekady w politycznej historii Europy przyniosły istotne zmiany znaczenia i roli granic państwowych. W zachodniej i środkowej części kontynentu, doświadczających procesu integracji europejskiej, zmniejszona została odgrywana przez nie rola (de-bordering). Efektem była idea Europy bez granic (borderless Europe), a nawet świata bez granic (borderless world). Jednakże w wyniku eliminacji bezpośrednich kontroli granicznych wewnątrz strefy Schengen, koniecznością okazała się ich intensyfikacja na granicach zewnętrznych. Zjawisko to zaczęto charakteryzować mianem twierdzy Europa (fortress Europe) ${ }^{1}$. W tym samym czasie, wschód i południe kontynentu, wraz z rozpadem Związku Radzieckiego i Jugosławii, doświadczyły odwrotnego procesu - przywracania granic i kontroli granicznych (re-bordering) pomiędzy nowoniepodległymi państwami.

Dynamizacja procesów integracyjnych w Europie dostarcza znacznej ilości tematów badawczych dla analizy politologicznej. Studia nad europeizacją, kolejnymi rozszerzeniami, reformą instytucjonalną, kryzysem ekonomicznym i politycznym itd., przyciagają uwagę badaczy, którzy próbują uchwycić przyczyny i dynamikę zjawiska oraz zbudować na ich podstawie instrumenty prognostyczne. Dominującą formą analizy jest koncentracja na państwach, narodach, instytucjach państwowych i ponadnarodowych, grupach społecznych, politykach sektorowych itd. Sa to w przeważającej większości kategorie makro, angażujące określoną

1 L. O'Dowd, T. Wilson, Frontiers of sovereignty in the new Europe, w: Borders of Europe, red. N. Alkan, Zentrum für Europäische Integrationsforschung, Bonn 2002, s. 8. 
perspektywę analityczną. Wydaje się, iż podejście mikro, skupiające się nie na wielkich agregatach, lecz mniejszych, a więc i łatwiej uchwytnych podmiotach, jest dużo rzadziej stosowane przez analityków.

Celem niniejszego artykułu jest przywołanie perspektywy mikro jako użytecznego podejścia w badaniu procesów integracyjnych. Zostanie ona osadzona w obszarze studiów granicznych, koncentrujących się na badaniu transformacji granic europejskich $\mathrm{w}$ wyniku procesów integracyjnych, ale także na zmianach koncepcji państwowości, terytorialności i suwerenności. Uważa się, iż są one widoczne na obrzeżach państw dużo intensywniej, niż w ich centrach. Refleksje teoretyczne i empiryczne dokonane zostaną na przykładzie granicznych miast bliźniaczych, jako transgranicznie integrujących się jednostkach samorządu terytorialnego w Europie. W trakcie analizy zasygnalizowane też zostaną główne różnice pomiędzy formą integracji miast w Europie Zachodniej i Środkowo-Wschodniej.

\section{Studia nad granicami}

Stworzenie teorii granic jest od wielu lat przedmiotem intensywnych starań wielu naukowców ${ }^{2}$. Przyjmuje się, iż istotą każdej struktury państwowej jest jego terytorium, w ramach którego następuje określony związek pomiędzy centrum i peryferiami. Historycznie, terytorialny wymiar państwowości w Europie charakteryzował się cechami jednego $\mathrm{z}$ trzech modeli: (neo)średniowiecznego, westfalskiego lub imperialnego ${ }^{3}$. Model (neo)średniowieczny cechował się dużą ilością jednostek o słabo zarysowanych centrach oraz peryferiach nierzadko nakładających się na siebie. W efekcie władza w centrum odznaczała się wysokim stopniem egzekwowalności. Peryferie kontrolowane były słabiej, nierzadko wspólnie z inną, sąsiednią jednostką. Sama istota granicy związana była z jej rozumieniem jako frontier - obszaru przenikania się kultur, języków, zwierzchności i kontroli. Westfalskie rozumienie terytorialnego wymiaru państwowości obejmowało natomiast wytyczenie linii granicznej rozgraniczającej wyłączne suwerenności. Granica zmieniła się w boundary

2 E. Brunet-Jailly, Theorizing Borders: An Interdisciplinary Perspective, „Geopolitics" 2005, vol. 10.

3 C. S. Browning, P. Joenniemi, Geostrategies of the European Neighbourhood Policy, „European Journal of International Relations” 2008, vol. 14, nr 3, s. 553. 
- linię separująca jednolite kulturowo, prawnie, językowo ${ }^{4}$ i politycznie struktury $^{5}$. Nadal istniejący podział na centra i peryferie minimalizowany był jednakże przez płynącą $\mathrm{z}$ centów i nierzadko narzucaną peryferiom standaryzację. Granica zmieniła się więc z obszaru kontaktu, gdzie mieszają się wpływy, w linię separacji, podkreślającą odmienność i relacje władzy. Model imperialny, stosowany przez państwa europejskie głównie poza granicami kontynentu, oznaczał koncentryczne kręgi wokół centrum, gdzie wraz z oddalaniem się, malały jego wpływy. Jednak nie oznaczało to pojawiania się oddziaływania innego centrum, a jedynie przestrzeń rozwojową dla eksportu idei, rozwiązań itd.

\section{Graniczne miasta bliźniacze jako anomalia w rozwoju polityczno-terytorialnym państw}

Graniczne miasta bliźniacze to organizmy miejskie położone bezpośrednio na granicy państwowej i posiadające swój odpowiednik po jej drugiej stronie.

W podejściu politologii, stosunków międzynarodowych, a nawet geografii politycznej czy społecznej uważa się nierzadko, że graniczne miasta bliźniacze stanowią anomalię w rozwoju politycznym i ekonomicznym państw ${ }^{6}$. W podejściu takim zwraca się uwagę na przestrzenny fenomen rozwoju państw i rozmieszczenia w nich miast. W logice westfalskiego porządku terytorialnego, ośrodki miejskie, będące jednocześnie centrami politycznymi, przemysłowymi, kulturalnymi, intelektualnymi itd., lokowane były zazwyczaj w centralnej części państwa. Był to obszar najłatwiejszy do obrony, znajdujący się daleko od granic, a więc i potencjalnych wrogów. Jednocześnie centralne położenie gwarantowało podobną odległość do peryferyjnych dzielnic, umożliwiając ich podobną kontrolę, egzekucję władzy oraz unifikację. Oznaczało to intensyfikację procesów dośrodkowych, szczególnie w okresie formowania

4 G. Custred, The linguistic Consequences of Boundaries, Borderlands, and Frontiers, „Journal of Borderland Studies” 2011, vol. 26, issue 3, s. 266.

5 L. K. D. Kristof, The Nature of Frontiers and Boundaries, „Annals of the Association of American Geographers" 1959, nr 3, vol. 49.

6 T. Lundén, European Twin Cities: models, examples and problems of formal and informal co-operation, „ISIG Quarterly of International Sociology” 2004, nr 3-4, s. 1. 
się państw narodowych. W tym samym paradygmacie przestrzenno-politycznym zawierał się jednak niedorozwój obszarów peryferyjnych. Tu, przede wszystkim z uwagi na potencjalne zagrożenie atakiem zewnętrznym, nie lokowano zasobów istotnych dla istnienia państwa. W efekcie większość miejscowości ma tam charakter wiejski lub małomiasteczkowy. Im bliżej granicy państwowej, tym zjawisko to wydaje się bardziej widoczne. Jak zauważa Moreno Zago po przebadaniu stu dwudziestu miast położonych w pobliżu jednej z czterdziestu jeden obecnych europejskich granic, nawet dzisiaj prawie połowa $\mathrm{z}$ nich ma poniżej dwudziestu pięciu tysięcy mieszkańców, jedna czwarta nie przekracza pięćdziesięciu tysięcy, a jedynie piętnaście procent liczy więcej niż siedemdziesiąt pięć tysięcy mieszkańców, a więc ma charakter miasta średniej wielkości ${ }^{7}$.

Pochodną struktury przestrzennej państw narodowych i rozmieszczenia zasobów wydaje się być poziom rozwoju i w efekcie zamożności. Centra, posiadające najważniejsze ośrodki miejskie, skupiają także w sobie bogactwo oraz stanowią podstawę rozwoju gospodarczego poprzez posiadany potencjał. Peryferie natomiast są bardzo często niedorozwinięte $\mathrm{z}$ uwagi na braki w posiadanym potencjale rozwojowym. Dodatkowo w warunkach konsolidacji państwa narodowego, rozwój infrastruktury transportowej, będącej jednym z głównym wyznaczników możliwości wykorzystania potencjału centrów przez peryferie, rozwijany był w kierunku od tych pierwszych, ku drugim. Oznaczało to, iż obszary przygraniczne były nie tylko najbardziej oddalone od centów, ale także, iż ich połączenie z centrami następowało najpóźniej, o ile w ogóle się dokonywało.

Proces integracji europejskiej zmienił rozumienie państwowości, również $\mathrm{w}$ jej przestrzennym wymiarze. Otwieranie, a następnie zanikanie granic państwowych (przynajmniej w ich fizycznym i kontrolnym aspekcie), związane było z umożliwieniem swobodnego przepływu dóbr, usług, osób i kapitałów. Jednakże jego podstawy związane były także z rosnącym zaufaniem między państwami, wyrażającym się w malejącej roli terytorialności i konieczności obrony własnego terytorium przed roszczeniami sąsiadów. Punkt ciężkości rozwojowej przesunięty został więc z centrów ku peryferiom. Dotychczas peryferyjne regiony znajdujące się na końcach terytorium, i będące najdalej wysuniętymi bastionami

7 M. Zago, The State of Cooperation between Border Towns, „ISIG Quarterly of International Sociology" 1999-2000, nr 4, s. 1-2. 
obrony (a tym samym obszarami niewartymi lokowania tam zasobów), stały się nagle łącznikami z innymi państwami. Istotniejsza od bezpieczeństwa stała się współpraca, która przedefiniowała rolę terytoriów granicznych. Stały się one nagle bramami, mostami, korytarzami itp. Zmiana ta otworzyła oczywiście olbrzymie możliwości rozwojowe dla ekonomicznie upośledzonych regionów. Jednakże szybko okazało się, iż mechanizm rynkowy nie jest zdolny do samoczynnego napędzania rozwoju tych regionów na oczekiwanym poziomie. Działo się tak nie tylko z uwagi na wieloletnie (często wielowiekowe) zaniedbania, lecz także na wyższe koszty: różne systemy prawne, ekonomiczne, kulturowe, językowe itp., po obu stronach granicy. Rozwój związany z transgranicznością wymagał więc dodatkowego wparcia finansowego, niwelującego nie tylko zapóźnienia, ale także trudności wynikające z samego faktu istnienia granicy. Rolę taką zaczęły odgrywać unijne instrumenty wsparcia finansowego dla współpracy transgranicznej, np. INTERREG ${ }^{8}$.

Zaprezentowane rozważania dotyczące zmian polityczno-przestrzennych oraz ekonomiczno-przestrzennych w procesie formowania państw narodowych oraz integracji europejskiej znajdowały swoje odzwierciedlenie także w samej koncepcji granicy. Europa przednarodowa charakteryzowała się granicami rozumianymi jako frontier (a więc obszar przenikania), narodowa jako boundary (czyli linii rozgraniczającej odrębne struktury i suwerenności). Proces integracji europejskiej przedefiniował ponownie granice. Wewnętrzne - w kierunku powrotu do frontier, gdzie otwartość i współpraca tworzą nowe jakościowo wymiary integracji. Zewnętrzne jednak w kierunku wzmocnienia boundary, jeszcze mocniej rozgraniczające unijną i pozaunijną rzeczywistość prawną, polityczną i ekonomiczną.

\section{Graniczne miasta bliźniacze jako przedmiot analizy}

Przywołany w poprzednim rozdziale argument o wyjątkowych charakterze miast granicznych wydaje się być jedynie pozornie zasadny. Bliższa analiza pokazuje, iż w Europie znajduje się ok. 1060 miast

8 S. E. Clarke, Spatial Concepts and Cross-Border Governance Strategies: Comparing North American and Northern Europe Experiences, paper presented at the EURA Conference on Urban and Spatial European Policies, Turin 18-20 April 2002 . 
leżących bliżej niż 25 kilometrów od granicy państwowej. Mieszka w nich $10 \%$ Europejczyków ${ }^{9}$. Dane te powodują, iż znaczenie anomalii dla analizy procesów integracyjnych wydaje się być większe, niż wynikałoby to z podejścia prezentowanego przez wielu badaczy.

Bliższego wyjaśnienia wymaga sama kategoria granicznych miast bliźniaczych. Pojęcie miast bliźniaczych stosowane jest do współpracy miast, nierzadko na znaczną odległość, położonych w różnych państwach. Jednakże w kontekście studiów granicznych rozumienie takie może być mylące. Tu za miasta bliźniacze uważa się najczęściej - za Helgą Schultz - „miasta oddzielone przez granicę państwową" ${ }^{\text {. Nicole }}$ Ehlers, Jan Buursink i Frans Boekema dodają, iż miasta takie - poza bezpośrednim sąsiedztwem - powinny być podobnego rozmiaru, oraz

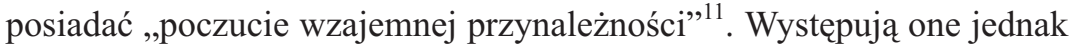
w literaturze i praktyce granicznej jako miasta połaczone (connected cities), miasta przekraczajace granice państwowa (border-corssing cities), miasta transgraniczne (trans-border cities), miasta partnerskie (partnership cities), miasta siostrzane (sister cities), bliźniaki miejskie (city twins), miasta podwójne (double cities) ${ }^{12}$, miasta podzielone (divided cities), miasta bliźniacze (twin cities) ${ }^{13}$, euro miasta (Euro cities), przygraniczne miasta podwójne ${ }^{14}$ i wiele innych. Jednakże większość tych nazw nie oddaje w pełni istoty omawianej kategorii badawczej. Niektóre $\mathrm{z}$ nich używane są jedynie regionalnie (np. miasta siostrzane - w Europie Wschodniej), inne zawierają w swym znaczeniu tylko część par, które są elementem omawianego fenomenu (np. miasta podzielone - tylko część pojawiła się na mapie w wyniku podziału). Jeszcze inne posiadaja

9 A. Gasparini, Do European Towns Hold the Key to Cultural Integration, Incubation?, Footnotes, December 2008, s. 1.

${ }^{10}$ H. Schulz, K. Stokłosa, D. Jajeśniak-Quast, Twin Towns on the Border as Laboratories of European Integration, FIT Discussion Paper, No. 4/2002, s. 3.

11 N. Ehlers, J. Buursink, F. Boekema, Introduction. Binational cities and their regions: From diverging cases to a common research agenda, „GeoJournal” 2001, nr 54, s. 1.

12 P. Joenniemi, A. Sergunin, When two aspire to become one: City-twinning in Northern Europe, DIIS Working Paper 2009, nr 21, s. 5.

13 B. J. S. Hoetjes, Trends and issues in municipal twinnings from the Netherlands, „Habitat International” 2009, vol. 33, issue 2.

14 M. Szalbot, Społeczno-kulturowa specyfika przygranicznych miast podwójnych Europy jako problem badawczy, w: Studia etnologiczne $i$ antropologiczne, t. 11: Etnologia na granicy, red. I. Bukowska-Floreńska, G. Odoja, Wydawnictwo Uniwersytetu Śląskiego, Katowice 2011. 
odmienne znaczenia tak akademickie, jak i polityczne (np. miasta bliźniacze - program współpracy miast w krajach europejskich) ${ }^{15}$. Dlatego nazwa granicznych miast bliźniaczych wydaje się najpełniej charakteryzować omawiany rodzaj miast.

Graniczne miasta bliźniacze mogą charakteryzować się dwojakim rodzajem relacji. Po pierwsze moga być to tzw. pary miast (town couple). Ich wzajemne stosunki cechują się konkurencją. Rywalizują one ze sobą w zakresie inwestycji, turystyki, infrastruktury, handlu itd. Po drugie, dominującą formą interakcji może być miasto podwójne (double town). W tym przypadku miasta uzupełniają się w zakresie posiadanych zasobów. Poprzez efekt synergii, maksymalizują swoją pozycję względem innych, konkurencyjnych miast po obu stronach granicy ${ }^{16}$.

$\mathrm{Z}$ punktu widzenia pochodzenia granicznych miast bliźniaczych warto wskazać na trzy kategorie: podzielone (divided), powielone (duplicated) oraz połaczone (connected).

Miasta podzielone powstały w wyniku przesunięcia granicy państwowej i przedzielenia nią istniejącego, niegranicznego organizmu miejskiego. Najczęściej (choć oczywiście nie zawsze) nowa granica przebiega wzdłuż rzeki. Rzeki natomiast stanowią oparcie dla centrów miast i ich oś rozwojową. Dlatego też, w przypadku miast podzielonych istotną rolę odgrywają dwie cechy: dziedzictwo jedności oraz bezpośrednia bliskość przestrzenna. Pierwsze przejawia się w pamięci historycznej dotyczącej okresu jedności, ale także pozostałości (nierzadko później przerwanych) powiązań infrastrukturalnych. Druga manifestowana jest przestrzenną spójnością organizmów miejskich. Bardzo często miasta takie nie rozwijają się koncentrycznie. Na ich styku (a więc tym samym na obrzeżach każdego z nich) znajdują się (historyczne) centra (będące pozostałością wspólnego centrum z czasu przed podziałem). Pozostałe dzielnice rozwijają się w jedynym możliwym kierunku - przeciwnym do granicy państwowej. Miasta takie sąsiadują więc ze sobą, są wzajemnie widoczne, a nierzadko nawet detale związane z codzienną aktywnością mieszkańców jednego miasta są obserwowalne przez mieszkańców drugiego bez przekraczania granicy.

W przypadku miast powielonych sytuacja jest odmienna. Jedno z miast istniało bezpośrednio przy granicy państwowej lub znalazło się

15 B. J. S. Hoetjes, Trends and issues..., op. cit.

16 H. Schulz, K. Stokłosa, D. Jajeśniak-Quast, Twin Towns on ..., op. cit., p. 4. 
tam w wyniku przesunięcia granicy. W efekcie zaczęło pełnić rolę bramy lub strażnicy danego terytorium. Po drugiej stronie granicy z czasem pojawiała się druga brama lub druga strażnica. Pierwszy z organizmów został uzupełniony partnerem po drugiej stronie granicy. Brakuje tu często dziedzictwa jedności, choć wspólnota dziejów bywa elementem tożsamości przestrzennej miast. Rola granicy jest podkreślana. Bliskość przestrzenna jest także elementem charakteryzującym miasta, jednakże nierzadko posiadają one odrębne własne centra, stykają się natomiast obrzeżami.

Miasta połaczone rozwijały się zazwyczaj niezależnie od siebie po obu stronach granicy. Ta ostatnia przebiegała wzdłuż mocno separującej przeszkody, zazwyczaj wodnej (bardzo szeroka rzeka, cieśnina itp.). Dopiero w wyniku budowy połączenia (most, tunel), niezależnie istniejące miasta zyskały infrastrukturalny potencjał intensyfikacji interakcji. W efekcie dziedzictwo jedności i poczucie wspólnoty dziejów nie istnieje lub jest bardzo słabe. Miasta są niezależnymi organizmami, z własnymi centrami i pełną infrastrukturą.

Helga Schultz identyfikuje ponad czterdzieści par granicznych miast bliźniaczych w Europie (czyli ponad osiemdziesiąt miast). Jednakże w zależności od zastosowanych kryteriów liczba ta może ulec zmianie. Klasyfikowane miasta różnią się statusem prawnym, wielkością, pary wewnątrz natomiast fizycznym oddaleniem od siebie oraz istniejącymi więzami pomiędzy tak mieszkańcami, jak i władzami. Po zastosowaniu bardziej restrykcyjnych kryteriów (dotyczących bezpośredniego położenia na granicy, a nie niedaleko od niej, efektywnych połączeń infrastrukturalnych, miejskiego charakteru potwierdzonego własnym samorządem itd.) nadal wyodrębnić można dwadzieścia trzy pary miast, czyli czterdzieści sześć miast (Tabela 1).

Graniczne miasta bliźniacze są więc fenomenem rozpowszechnionym w Europie. Można napotkać je na większości granic państwowych (Mapa 1). Jednakże istnieją pewne cechy różnicujące ich charakter w różnych częściach kontynentu. Jedną z nich jest niewątpliwie moment powstania. Jest on związany ze stałością granic. Generalizując, należałoby przyjąć, iż im starsze granice w danej części Europy, tym historycznie odleglejszy moment powstania granicznych miast bliźniaczych. Pojawiały się one na mapie w kilku falach. Istnieje grupa - głównie na Półwyspie Pirenejskim - sięgająca swoimi korzeniami czasów średniowiecza. Kolejna faza ich powstawania związana jest z okresem napoleońskim i jego konsekwencjami w pierwszych dekadach dziewiętnastego wieku. Wtedy to pojawiła się grupa par miast w Europie Zachodniej 
oraz Skandynawii. Następny etap wynikał z efektów pierwszej wojny światowej oraz odzyskania lub uzyskania niepodległości przez szereg państw w Europie Środkowej. Kolejne pary miast to rezultat przesunięcia granic w wyniku drugiej wojny światowej, głównie w Europie Środkowo-Wschodniej. Ostatnia faza to produkt dezintegracji Związku Radzieckiego, ale także - proces trwający do dzisiaj - kształtowania się nowego porządku polityczno-terytorialnego na obszarze byłej Jugosławii.

Tabela 1

Graniczne miasta bliźniacze w Europie

\begin{tabular}{|c|c|c|}
\hline L.p. & Miasta & Granica \\
\hline 1 & 2 & 3 \\
\hline 1 & Baarle Hertog - Baarle Nassau ${ }^{17}$ & Belgia - Holandia \\
\hline 2 & Bad Radkersburg - Gornja Radgona & Austria - Słowenia \\
\hline 3 & Český Těšin - Cieszyn ${ }^{18}$ & Czechy - Polska \\
\hline 4 & Esztergom - Stúrovo & Węgry - Słowacja \\
\hline 5 & Frankfurt n. Odrą - Słubice ${ }^{19}$ & Niemcy - Polska \\
\hline 6 & Giurgiu - Ruse & Rumunia - Bułgaria \\
\hline 7 & Gmünd - Česka Velenice & Austria - Czechy \\
\hline 8 & Gorizia Nova - Gorica ${ }^{20}$ & Słowenia - Włochy \\
\hline 9 & Görlitz - Zgorzelec ${ }^{21}$ & Niemcy - Polska \\
\hline
\end{tabular}

17 C. d'Olivier Farran, International Enclaves and the Question of State Servitudes, „International and Comparative Law Quarterly” 1955, vol. 5, issue 2, s. 299; H. M. Catudal, Exclaves, „Cahiers de géographie du Québec” 1974, vol. 18, nr 43, s. 123; M. Abbenhuis, Where war met peace: the borders of the neutral Neitherlands with Belgium and Germany in the first world war, 1914-1918, „Journal of Borderland Studies" 2007, vol. 22, issue 1.

18 K. Kulczyńska, R. Matykowski, Struktura przestrzenno-handlowa przygranicznego zespołu miejskiego Česky Těšin - Cieszyn, „Dokumentacja Geograficzna” 2008, nr 36.

19 K. Dascher, The Cross Region of Frankfurt (Oder) - Stubice: An Economic Perspective, Economics Departament, European University Viadrina, Frankfurt (Oder) 2003.

20 A. Gasparini, E. Sussi, Gorizia - Nova Gorica: Scenarios for a New City, „ISIG Quarterly of International Sociology” 1991, nr 1.

21 E. Lemper, Görlitz. Eine historische Topographie, Zittau 2009. 


\begin{tabular}{|c|c|c|}
\hline 1 & 2 & 3 \\
\hline 10 & Guben - Gubin ${ }^{22}$ & Niemcy - Polska \\
\hline 11 & Haparanda - Tornio ${ }^{23}$ & Szwecja - Finlandia \\
\hline 12 & Irún/Hondarribia - Hendaye & Hiszpania - Francja \\
\hline 13 & Kerkrade - Herzogenrath ${ }^{24}$ & Holandia - Niemcy \\
\hline 14 & Komárom - Komárno ${ }^{25}$ & Węgry - Słowacja \\
\hline 15 & Laufen - Oberndorf ${ }^{26}$ & Niemcy - Austria \\
\hline 16 & Laufenburg - Laufenburg ${ }^{27}$ & Niemcy - Szwajcaria \\
\hline 17 & Lifford - Strabane & Irlandia - Wielka Brytania \\
\hline 18 & Narva - Iwangorod ${ }^{28}$ & Estonia - Rosja \\
\hline 19 & Rheinfelden - Rheinfelden ${ }^{29}$ & Niemcy - Szwajcaria \\
\hline 20 & Stasbourg - Kehl & Francja - Niemcy \\
\hline 21 & Valença - Tui & Portugalia - Hiszpania \\
\hline 22 & Terespol - Brześć & Polska - Białoruś \\
\hline 23 & Valka - Valga ${ }^{30}$ & Lotwa - Estonia \\
\hline
\end{tabular}

Źródło: Opracowanie własne.

22 U. Matthiesen, H. Bürkner, Antagonistic structures in border areas: Local milieux and local politics in the Polish-German twin city Gubin/Guben, „GeoJournal” 2001, nr 54.

23 T. Lundén, D. Zalamans, Local co-operation, ethnic diversity and state territoriality - The case of Haparanda and Tornio on the Sweden - Finland border, „GeoJournal” 2001, nr 54.

24 N. Ehlers, J. Buursink, Binational cities: People, Institutions, and Structures, in: Borders, Regions, and People, M. van der Velde, H. van Houtum, London 2000.

25 G. Medve-Bálint, S. Svensson, Explaining coverage: why local governments in Central Europe do or do not join Euroregions?, w: The Border Multiple. The Practicing of Borders between Public Policy and Everyday Life in a Re-scaling Europe, red. D. Jagetić Andersen, M. Klatt, M. Sandberg, Furnham 2012.

${ }^{26}$ Laufen und Oberndorf. 1250 Jahre Geschichte, Wirtschaft und Kultur an beiden Ufern der Salzach, red. H. Dopsch, H. Roth, Laufen 1998.

27 A. Lüthi, Geschichte der Stadt Laufenburg, Band 3, Laufenburg 1986.

28 T. Lundén, European Twin Cities: models, examples and problems of formal and informal co-operation, „ISIG Quarterly of International Sociology” 2004, nr 3-4.

29 K. Schib, Geschichte der Stadt Rheinfelden, Rheinfelden 1961.

30 T. Lundén, D. Zalamans, ,, National Allegiance” and Spatial Behaviour in Balic Boundary Twins Towns, „Jurnal of Baltic Studies” 2002, vol. 33. 


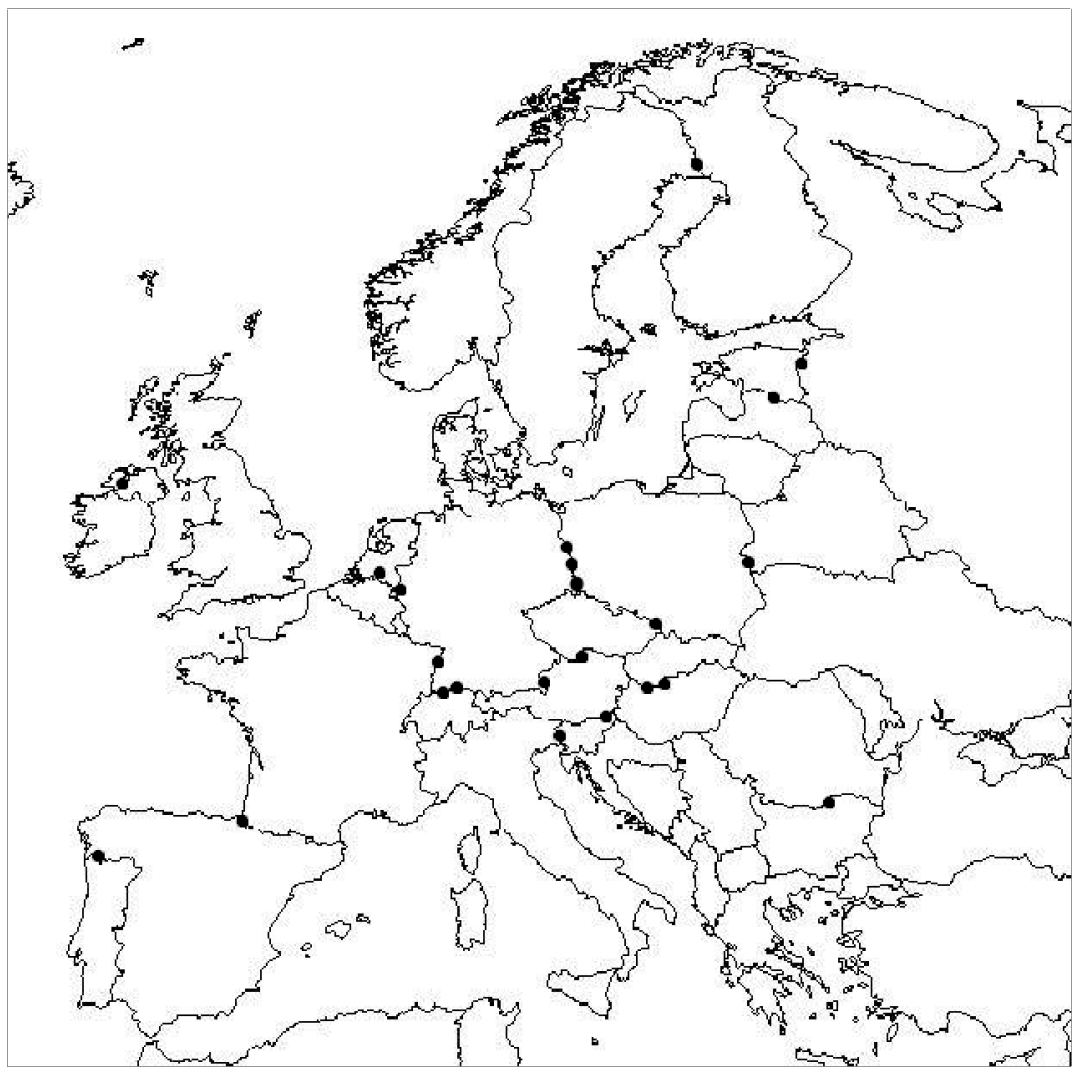

Mapa 1. Graniczne miasta bliźniacze w Europie Źródło: Opracowanie własne.

\section{Wspólpraca i integracja w granicznych miastach bliźniaczych}

Jednym z głównych sporów w badaniu interakcji pomiędzy granicznymi miastami bliźniaczymi jest pytanie, czy ich istota jest 1) poprawa pozycji własnego miasta $\mathrm{w}$ kontekście systemu narodowego ${ }^{31}$, czy też 2) stanowią one (jako pary) emanację konceptu integracyjnego, który wyrażony w mikroskali staje się laboratorium integracji europejskiej ${ }^{32}$.

31 H. van Houtum, H. Ernste, Re-imagining spaces of..., op. cit., s. 103.

32 Ibidem. 
1) Pierwsze z podejść zakłada, iż współpraca wewnątrz par jest przede wszystkim strategią rozwojową. Jej wyrazem jest pragmatyzm instytucjonalny lokalnych struktur administracyjnych. Pozostają one nadal zorientowane wewnętrznie. Współpraca transgraniczna oraz wizerunek otwartych, międzynarodowych i dynamicznych struktur miejskich jest jedynie instrumentem wygrywania rywalizacji z innymi miastami, położonymi wewnątrz własnego państwa.

Podejście to zakłada, iż kwestie współpracy i rywalizacji miast stanowiących pary wymaga spojrzenia przez pryzmat dwóch poziomów analizy: władz lokalnych oraz mieszkańców. O ile te pierwsze zazwyczaj w ścisłych związkach z druga stronq upatrują szans rozwojowych, o tyle ci drudzy nierzadko nie podzielają urzędowego optymizmu i niechętnie angażują się w inicjatywy motywowane odgórnie ${ }^{33}$. Władze lokalne reprezentują najczęściej pragmatyzm instytucjonalny. Polega on na niemal automatycznym angażowaniu się we współpracę transgraniczną, widząc w niej możliwość pozyskania zewnętrznego (narodowego, unijnego) wsparcia dla wspólnych inicjatyw. Wsparcie takie - nierzadko mierzone w milionach euro i skutkujące istotnymi inwestycjami infrastrukturalnymi, społecznymi, kulturalnymi - byłoby niemożliwe do uzyskania bez wykazania elementu transgranicznego ${ }^{34}$. Z drugiej strony mieszkańcy reprezentują częstokroć postawę alienacji społecznej. Polega ona na niechętnym wchodzeniu w inne niż komercyjne (zakupy, usługi itp.) interakcje z przedstawicielami społeczności po drugiej stronie granicy i koncentracji zachowań społecznych w ramach własnej grupy narodowej ${ }^{35}$. Jednocześnie jednak, w warunkach, gdy granica państwowa przecina relatywnie homogeniczny (etnicznie, kulturowo, funkcjonalnie itd.) obszar, lokalne struktury - również społeczne - dążą zazwyczaj do przezwyciężania jej izolującego charakteru ${ }^{36}$.

33 N. Ehlers, J. Buursink, F. Boekema, Introduction. Binational cities..., op. cit., s. 1 .

34 J. Jańczak, Cross-border governance jako koncepcja wspólnego zarzqdzania miastem podzielonym. Efektywność w warunkach członkostwa w UE, w: Pogranicze polsko-niemieckie po 2004 roku. Nowa jakość sqsiedztwa?, red. J. Jańczak, M. Musiał-Karg, Toruń 2009.

35 J. Jańczak, Cross-border governance jako podstawa zaawansowanej wspótpracy polsko-niemieckiej w regionach przygranicznych, w: Polityka Sasiedztwa Unii Europejskiej. Pomostowość czy buforowość?, red. J. Jartyś, A. Staszczyk, Szczecin 2008.

36 A. Gelbman, D. J. Timothy, Border complexity, tourism and international exclaves, „Annals of Tourism Research” 2011, vol. 38, issue 1, s. 112. 
2) Druga z perspektyw widzi ten proces zupełnie inaczej. Tutaj w sposób funkcjonalny miasta transgraniczne stają się - wraz z procesem zanikania granic państwowych - inicjatorami i prekursorami integracji europejskiej. To one (niezależnie od własnej woli) jako pierwsze doświadczają - z uwagi na przestrzenną bliskość oraz istniejące związki funkcjonalne ze swoim bliźniakiem po drugiej stronie granicy - większości pozytywnych i negatywnych efektów integracji. Stają się więc laboratoriami, gdzie projekt europejski widoczny jest w odnotowywanej skali i może poddany być dużo efektywniejszej obserwacji w zakresie różnic, podobieństw i wzajemnych interakcji narodowych systemów politycznych, prawnych, ekonomicznych, kulturowych, językowych itp. Pertti Jaenniemi i Alexander Sergunin zauważają, iż współpraca międzynarodowa jest zawsze tożsama $\mathrm{z}$ eksperymentowaniem ${ }^{37}$. Jest to szczególnie widoczne $\mathrm{w}$ granicznych miastach bliźniaczych, charakteryzujących się z natury otwartością i kosmopolityzmem ${ }^{38}$.

Istotą metafory laboratorium $^{39}$ jest zmiana skali obserwacji. Laboratorium to nie rzeczywistość społeczna w realnym wymiarze (trudno obserwowalna z uwagi na rozmiar i wielość zachodzących w niej procesów), lecz jej wycinek. Fragment, który w relatywnie dających się kontrolować warunkach pozwala na lepszą i bardziej efektywną obserwację zachodzących procesów. Ale daje on także możliwość eksperymentowania. Poprzez odpowiednią stymulację (np. w zakresie określonych polityk, alokacji zasobów, rozwiązań prawnych itd.) pozwala na badanie efektów tych działań. Jeżeli są one satysfakcjonujące, daje to możliwość przenoszenia rozwiązań ze skali mikro, w wymiar makro - aplikacji do systemu międzypaństwowego. Alberto Gasparini określa graniczne miasta bliźniacze jako laboratoria integracji zróżnicowanej (laboratories of differentiated integration) ${ }^{40}$. Widzi

37 P. Jaenniemi, A. Sergunin, When two aspire to become one: City-twinning in Northern Europe, „Journal of Borderland Studies” 2011, vol. 26, issue 2, s. 233.

38 A. Gasparini, Do European Towns Hold the Key to Cultural Integration, Incubation?, Footnotes, December 2008.

39 Pojęcie laboratorium używane jest w literaturze przedmiotu zarówno jako sztucznie wykreowana rzeczywistość, jak i realnie istniejący fragment podlegający badaniom terenowym. Szerzej: J. A. Laponce, Experimenting: a two-person game between man and nature, w: Experimentation and simulation in political science, red. J. A. Laponce, P. Smoker, Rotonto 1972.

40 A. Gasparini, European Border Towns as Laboratories of Differentiated Integration, „ISIG Quarterly of International Sociology” 1999-2000, nr 4. 
on w nich zasób ukazujący różne obszary o odmiennych potencjałach integracyjnych.

Graniczne miasta bliźniacze testują też jeszcze jeden element, tym razem specyficzny dla nich i innych jednostek (np. regionów) położonych bezpośrednio przy granicy państwowej. Jest to zdolność do projektowania i wdrażania mechanizmów zarzqdzania transgranicznego (cross-border governance ${ }^{41}$ ). Element ten jest niezwykle istotny w warunkach liberalizacji granicznej i zanikania granic, przy konieczności zarządzania kwestiami przekraczającymi granice państwowe. Jego istotą jest aspekt terytorialny i funkcjonalny ${ }^{42}$. Enrico Gualini w swoich analizach zarządzania transgranicznego zwraca uwagę na trzy jego wymiary: polityczno-ekonomiczny, instytucjonalny oraz symboliczno-kognitywny ${ }^{43}$. Jego zdaniem, dla sprawnego zarządzania przestrzenią transgraniczną niezbędna jest po pierwsze zdolność do postrzegania jej jako jednolitego obszaru rozwojowego, w którym należy budować wspólne cele. Po drugie, wymiar instytucjonalny konstytuuje tworzenie nowych, transgranicznych struktur i/lub współpracę istniejących struktur w ramach porządków prawno-instytucjonalnych państw sąsiedzkich. Po trzecie, wymiar symboliczny dotyczy zdolności budowania tożsamości lokalnych o transgraniczym charakterze, integrujących i uzupełniających tożsamości narodowe.

Zaprezentowane podejście nie jest fenomenem jedynie analitycznym. Na płaszczyźnie politycznej znajduje swój wyraz w unijnym wsparciu dla współpracy transgranicznej. Polityka rozwojowa Wspólnot Europejskich bazuje na głębokim przekonaniu, że w kontekście procesu integracji europejskiej, miasta i regiony peryferyjne w jednym państwie powinny zostać zwiqzane z miastami i regionami peryferyjnymi w państwie sąsiednim. Uważa się, iż z przyczyn przestrzenno-strukturalnych cechują się one podobną strukturą problemów, w tym rozwojowych. Dlatego ich współpraca powinna być celowa $\mathrm{z}$ uwagi na komplementarność celów i szans ${ }^{44}$.

41 M. Perkmann, Building governance institutions across European Borders, „Regional and Federal Studies” 1999, vol. 33(7).

J. Blatter, 'From Spaces of Place' to 'Spaces of Flows'? Territorial and Functional Governance in Cross-border Regions in Europe and Northe America, „International Journal of Urban and Regional Research" 2004, vol. 28, nr 3.

43 E. Gualini, Cross-border Governance: Inventing Regions in a Trans-national, Multi-level Polity, DISP Working Paper 2003, nr 152, s. 44-45.

44 H. van Houtum, H. Ernste, Re-imagining spaces of..., op. cit., s. 104. 


\section{Integracja funkcjonalna w mikroskali}

Szukając obszaru, w którym integracja granicznych miast bliźniaczych jest wysoce widoczna, warto zwrócić uwagę na wspólne strategie rozwoju ekonomicznego w zakresie turystyki transgranicznej, tak w zakresie ich tworzenia, jak i wdrażania. Bazują one na funkcjonalnie zdefiniowanym założeniu o dużo efektywniejszym zaspokajaniu potrzeb w zakresie rozwoju gospodarczego poprzez tworzenie wspólnego systemu przyciagania turystów.

Tradycyjnie granica jest turystycznie nieatrakcyjna: jest raczej elementem - dodatkowo problemowym bo związanym z kontrolami, formalnościami, stratą czasu - w docieraniu $\mathrm{z}$ jednego miejsca docelowego do innego ${ }^{45}$. Wpisuje się tym samym w ogólny wizerunek peryferii jako zapóźnionych rozwojowo i nieatrakcyjnych. Jednakże okazuje się, iż granica, oczywiście odpowiednio przepuszczalna (czyli taka, która nie generuje uciążliwości, a oferuje potencjalne zyski) tak jak granice wewnętrzne Unii Europejskiej, stanowią atrakcję dla turystów. Szczególnie, jeżeli obie strony współpracują w tworzeniu i promowaniu tej atrakcyjności. Przyciagają one uwagę najczęściej dwoma elementami: unaocznieniem linii granicznej oraz ofertą komercyjną wynikającą z bliskości przestrzennej dwóch różnych reżimów komercyjnych, podatkowych i prawnych.

Granica, linia graniczna, możliwość jej przekraczania, doświadczania i uwieczniania stają się ciekawym doświadczeniem dla wielu turystów. W granicznym mieście bliźniaczym można być „w dwóch miejscach jednocześnie". Poprzez zmianę skali, odwiedzający doświadcza dwóch kultur, języków, potraw narodowych lub regionalnych itd., przebywając w jednym miejscu i wielokrotnie przekraczając granicę. Odczucie różnorodności staje się elementem pozwalającym na dostrzeżenie integracji kontynentalnej w namacalnej skali. Przejawem, w jaki władze granicznych miast bliźniaczych wykorzystują ten element jest zjawisko redemarkacji linii granicznej. Jest ona upamiętniana w postaci pomników, tablic oraz plakietek na elementach małej architektury miejskiej, zazwyczaj w miejscach, gdzie w wyniku zaniku granic, pozbyto się jej atrybutów (punktów kontroli granicznych, słupów granicznych itp.). Pozwala to na fizyczne doświadczanie granicy.

45 A. Gelbman, D. J. Timothy, Border complexity, tourism..., op. cit., s. 113. 
Komercyjny, podatkowy i prawny aspekt turystyki granicznej związany jest $\mathrm{z}$ różnicami $\mathrm{w}$ cenach produktów (będących pochodną różnych stawek procentowych VAT, ale także różnych kosztów pracy) i usług. Jednocześnie zdarza się, iż odmienne uregulowania prawne dotyczące np. hazardu, pozwalają na przyciąnnięcie turystów do jednej z części granicznego miasta bliźniaczego. Podobnie jak odmienne godziny i dni otwarcia punktów handlowych ${ }^{46}$.

\section{Integracja symboliczna w mikroskali}

W badaniach nad instytucjonalizacją regionów transgraniczych zwraca się uwagę na fakt, iż jest ona wyrazem przeskalowania siły państwa, która następuje w kierunku ponadnarodowym i subnarodowym. Produkcja i konsumpcja nie następują już w granicach państw narodowych, lecz poprzez zwiększenie skali $\mathrm{w}$ instytucjach międzynarodowych i ponadnarodowych (NATO, Unia Europejska), poprzez zmniejszenie w jednostkach samorządu terytorialnego (regiony, miasta) ${ }^{47}$.

Graniczne miasta bliźniacze często podkreślają, iż ich rola w procesie integracji europejskiej jest kluczowa, a one same są laboratoriami tego procesu. Jednakże mając na uwadze różne kierunki przemiany granic wewnętrznych (eliminacja kontroli) i zewnętrznych (ich wzmocnienie) oraz różne tradycje i okoliczności w jakich miasta te powstały, należy zwrócić uwagę, iż symboliczny wymiar (dez)integracji widoczny w przeskalowaniu wygląda różnie w rożnych miastach.

1) Na granicy zewnętrznej jest to postępująca izolacja. W przypadku Narwy i Iwangorodu, reborderyzacja wyeliminowała z codziennego życia mieszkańców element swobodnego przepływu ${ }^{48}$, obecny za czasów sowieckich. W wyniku ogłoszenia niepodległości przez Estonię, a następnie przystapienia przez to państwo do Unii Europejskiej i strefy Schengen, nastapiło stopniowe acz konsekwentne rozdzielenie nie tylko

46 D. J. Timothy, Political boundaries and tourism: borders as tourist attractions, „Tourism Management” 1995, vol. 16, nr 7, s. 529-530.

47 M. Antonsich, Exploring the Correspondence Between Regional Forms of Governance and Regional Identity: The Case of Western Europe, „European Urban and Regional Studies" 2010, vol. 17, nr 3, s. 262-263.

48 R. Kaiser, E. Nikiforova, The performativity of scale: the social construction of scale effects in Narva, Estonia, „Environment and Planning D: Society and Space" 2008, vol. 26, s. 545. 
wspólnej infrastruktury i porządków prawnych, ale także podział lokalnej społeczności na dwie grupy. Posiadają one inne obywatelstwa, ale także inne prawa i obowiązki, co rozpoczęło różnicowanie ich tożsamości. W Narwie nastąpiło zmniejszenie skali percepcji rzeczywistości. $\mathrm{W}$ efekcie jej relacje $\mathrm{z}$ Iwangorodem, postrzegane są jako uosabiające Estonię lub nawet Europę w relacjach z Rosją. Jej odcięcie się od rosyjskiego bliźniaka (także poprzez przywracanie architektonicznego i językowego charakteru sprzed drugiej wojny światowej) interpretowane są jako reesotnizacja tego miasta oraz jego reeuropeizacja. Granica opisywana jest jako linia wymagająca obrony przed czyhającym tuż obok zagrożeniem. Narwa uosabia więc procesy zachodzące w całej Estonii ${ }^{49}$.

2) Na granicach wewnętrznych, głównie w Europie Środkowej, choć także w Europie Zachodniej, dominuje europejska interpretacja integracji miast, gdzie symbolizują one jednoczenie się kontynentu w mikroskali. Graniczne miasta bliźniacze w regionie doświadczają określonych zjawisk jako forpoczta danego kraju. Tak stało się w latach dziewięćdziesiątych dwudziestego wieku z miastami położonymi na zachodniej granicy Europy Środkowej. Wschodni partnerzy - dzięki intensywnej współpracy ze swoimi zachodnimi bliźniakami, dużo wcześniej doświadczali realiów integracji europejskiej w ich materialnym i formalnym charakterze ${ }^{50}$. Jednym z przejawów tego zjawiska jest określanie się mianem miasta europejskiego. Szyld ten podkreśla z jednej strony jedność ponad granicami państwowymi (dwa miasta ulokowane w odrębnych państwach tworzą jedno miasto). Z drugiej natomiast akcentuje europejski (a więc nie narodowy) charakter tego procesu. Kerkerade i Herzogenrath powołały do życia taką strukturę w roku 1997 (Eurocity) jako Eurode (nazwa powstała z połączenia słów Europa i Rode - dawny zamek w miejscu, gdzie obecnie znajdują się oba miasta). Frankfurt nad Odrą i Słubice posługują się nazwą Dwumiasto (Doppelstadt), Görlitz i Zgorzelec powołały w roku 1998 Europamiasto Zgorzelec/Görlitz (Europastadt Görlitz/Zgorzelec). Haparanda i Tornio używały początkowo określenia miasto bliźniacze (twin city), co w roku 2002 zastapiono euromiastem (EuroCity), działającym pod sloganem HaparandaTornio międzynarodowe miejsce spotkań (HaparandaTornio International Me-

49 R. Kaiser, E. Nikiforova, The performativity of scale..., op. cit., s. 549.

50 M. Szalbot, Społeczno-kulturowa specyfika..., op. cit., s. 147. 
eting-Place $)^{51}$. Jednakże wkrótce wrócono do starej nazwy pod wpływem protestów, szczególnie po szwedzkiej stronie granicy.

3) Niektóre z par nie przeskalowują lokalnej integracji w interpretacji kontynentalnej, lecz czynią to w logice międzypaństwowej lub regionalnej. Elementy europejskie nie występują wtedy w symbolice. Komárno i Komárom prezentują się jako dwa państwa, jedno miasto (two states and one town). Baarle-Nassau i Baarle Hertog reklamują się jako jedna miejscowość, dwie społeczności, dwa narody (one village, two communities, two nations) ${ }^{52}$. Laufenburg (Baden) i Laufenburg (AG) natomiast jako dwa państwa jedno miasto (Zwie Länder eine Stadt). Obydwa Rheinfelden reklamują się informując, że Reinfelden taczy (Rheinfelden verbindet).

\section{Zakończenie}

Integracja graniczna jest wyrazem szerszych procesów jednoczenia się określonych struktur. Stanowi jednocześnie manifestację opinii, iż ludzie myślą globalnie, lecz funkcjonują lokalnie ${ }^{53}$. Europejska perspektywa integracyjna znajduje więc swoją namacalną implementację w przypadku struktur mikro. A ich widocznym przykładem są graniczne miasta bliźniacze. Jednocześnie należy pamiętać, iż wraz z utratą znaczenia przez granice polityczne i zmianę ich tradycyjnej roli barier, granice mentalne, ekonomiczne, kulturowe i inne zaczęły odgrywać ważniejszą rolę we wzajemnych relacjach ${ }^{54}$. Dlatego też niektórzy badacze zwracają uwagę na rolę imigrantów, lub szerzej, ludności innej niż dominujące po obu stronach granicy narody, w integracji miast.

Watro zauważyć, iż granice państwowe są produktem przeszłości, nierzadko problematycznej i wynikającej z wojen, konfliktów, traktatów pokojowych i kompromisów międzypaństwowych. Zmiana przebiegu granic lub redefinicja ich roli i znaczenia wiąże się w efekcie $\mathrm{z}$ ingerowaniem $\mathrm{w}$ przeszłość ${ }^{55}$. Zmiana $\mathrm{w}$ postrzeganiu roli granicznych miast

51 P. Jaenniemi, A. Sergunin, When two aspire..., op. cit., s. 236.

52 A. Gelbman, D. J. Timothy, Border complexity, tourism..., op. cit., s. 111.

53 H. van Houtum, H. Ernste, Re-imagining spaces of..., op. cit., s. 104.

54 N. Ehlers, J. Buursink, F. Boekema, Introduction. Binational cities..., op. cit., s. 1.

55 L. O’Dowd, T. Wilson, Frontiers of sovereignty..., op. cit., s. 8. 
bliźniaczych przez centra sprowadza się w opisanym kontekście do zastapienia koncepcji ziemi niczyjej (no-man's land) w ideę przestrzeni wspólnej (common land) ${ }^{56}$.

\title{
European integration in microperspective. Border twin towns in Western and Central Europe
}

\begin{abstract}
Summary
The dynamization of integration processes in Europe has generated numerous research topics for political analysis. Border integration is an expression of the broader unification processes of certain structures. It is also a manifestation of the observation that people think globally, but function locally. The European integration perspective is therefore practically implemented in micro structures, exemplified by border twin towns.

The objective of this paper is to revive the micro perspective as a useful approach in the investigation of integration processes. This perspective is applied in the field of border studies, which focus on research into the transformation of European borders resulting from integration processes, as well as on the transformations of the concepts of statehood, territoriality and sovereignty. It is assumed that these phenomena are definitely more observable at the outskirts of states than in their centers. Theoretical and empirical considerations are based on the example of border twin towns, as the European units of local government that integrate across borders. The main differences between the integration of towns in Western Europe and Central and Eastern Europe are also indicated in the analysis.
\end{abstract}

${ }^{56}$ H. van Houtum, H. Ernste, Re-imagining spaces of (in) difference: Contextualising and reflecting on the intertwining of cities across borders, „GeoJournal” 2001, nr 54, s. 102. 
